\title{
The Intertwined Geopolitics and Geoeconomics of Hopes/Fears: China's Triple Economic Bubbles and the ‘One Belt One Road’ Imaginary
}

\author{
Ngai-Ling Sum, Politics Philosophy and Religion Department, Lancaster \\ University
}

\section{DOI: $10.1080 / 21622671.2018 .1523746$}

To link to this article: https://doi.org/10.1080/21622671.2018.1523746

\begin{abstract}
This article adopts a discursive-cum-material approach to China's new 'One Belt One Road' (OBOR) geostrategic imaginary and its development through the intertwining of geopolitics and geoeconomics of hopes and fears. It first contextualizes this development after the 2008 financial crisis when China promoted a vast stimulus package that inflated existing property and infrastructure bubbles and fuelled another in finance. Resulting debates over crisis management enabled an incoming President $\mathrm{Xi}$ to articulate a set of hope-based discourses that came to include 'China Dream', 'new normal', and OBOR. Familiar cartographic statecraft techniques and novel spatial metaphors were used to promote OBOR's allegedly 'win-win' strategy discursively. The OBOR imaginary was translated materially, and importantly, into policies that promoted a grand trans-regional 'spatial fix' to postpone China's over-accumulation crises. This strategy is consolidating a China-oriented infrastructural mode of growth in production, financial and security. As this absorbs ever more productive and financial capital, we see the emergence of contradictions, antagonisms, and conflicts, especially in the use of bilateral loan-debt contractuality to appropriate strategic infrastructure. The article concludes with a call for an affective turn examining the intertwining of geoeconomics and geopolitics in the analysis of trans-regional spatial fixes.
\end{abstract}

Keywords: Geoeconomics and geopolitics, hopes and fears, political economy, property and financial bubbles, loan-debt investment, infrastructural mode of growth, China, One Belt One Road 


\section{The Intertwined Geopolitics and Geoeconomics of Hopes/Fears: China's}

Triple Economic Bubbles and the 'One Belt One Road' Imaginary

\section{Ngai-Ling Sum, Politics Philosophy and Religion Department, Lancaster University}

\section{INTRODUCTION}

This article proposes a discursive-cum-material approach to the 2013 launch and later development of China's 'One Belt One Road' (OBOR) 1 geostrategic imaginary. The analysis unfolds in six steps. First, theoretically, it suggests that geostrategic imaginaries articulate geopolitics and geoeconomics and can be fruitfully related to the discourses of hopes and fears. Second, historically, it relates the OBOR imaginary to domestic issues in China following the 2008 financial crisis as the economic slowdown challenged the government's target of maintaining an 8 percent growth rate. Responding to this challenge and the resulting threats to employment, the leadership launched a vast stimulus package in that year. Yet, this intensified the property, infrastructure and, later, financial bubbles. These problems continued after the 2013 transfer of leadership from President Hu and Premier Wen to President Xi and Premier Li. Third, anticipating major economic reforms, a new term, 'Likonomics', was floated but was soon superseded by Xi's hope-based 'new normal' discourses with the OBOR imaginary as its linchpin. Fourth, discursively, this imaginary built on China's existing 'Go Out' and 'Go West' policies and constructed a new trans-regional scale of connectivity and win-win solutions via cartographic statecraft and geoeconomic/geopolitical tropes. Fifth, drawing on the notion of spatial fix, it examines how the translation of this imaginary into policies contributes to the building of a Chinaoriented infrastructural mode of growth based on three emerging governance configurations for production, finance and security respectively. As this mode of growth absorbs more and more production and financial capital, it is also prone to contradictions, conflicts and antagonisms. Sixth, highlighting key features of the OBOR case, the article explores the articulation of materiality and discourse in the making of spatial fixes at the interface of geopolitics and geoeconomics as these are shaped by openly voiced hopes and fears. 


\section{GEOSTRATEGIC IMAGINARIES AND THE INTERTWINING OF HOPES AND FEARS}

Geostrategic imaginaries and projects such as OBOR reflect the increasing global entanglement of geopolitics and geoeconomics (Sparke, 2014). Such imaginaries and their translation into policies and practices invite a critical discursive-material perspective (Sum and Jessop, 2013) on the interrelations among politics, economics and sociospatiality (Elden, 2013). Geopolitically, this includes how intellectuals of statecraft (cf. Foucault, 1980, 2008), such as foreign policy advisors, construct new geostrategic imaginaries in policy discourses. Literature on critical geopolitics indicates that most foreign policy discourses rest on spatial/scalar narratives and imaginaries that tend to deploy binaries such as East/West, them/us, and hopes/fears (e.g., Ashley, 1987; Booth and Wheeler, 2008; Campbell, 1998; Dalby, 1991). This perspective is echoed in critical geography (e.g., Agnew and Corbridge, 1995; Ó Tuathail and Agnew, 1992) as its proponents seek to overcome the state-centric territorial trap (Agnew, 1999) by exploring: (1) the complexities of spatialization and rescaling in regard to new state spaces; cross-border regions, military developmental statecraft (e.g., Brenner, 2003; Gregory, 2008; Jessop, 2008, 2016; Paasi, 2004; Perkmann and Sum, 2002); and (2) territorially-relevant subjectivation and identitybuilding in the core (Campbell, 1998) and periphery (e.g., Essex, 2013; Sparke, 2007; Sum, 2013).

The same critical perspective is pertinent to geoeconomics. The latter was first mapped for the post-Cold War period by a security consultant, Edward Luttwak (1990), who claimed that civilian innovation potential, international trade, and market penetration would replace military power as the dominant mode of world ordering. This would create new hierarchies among nations. This approach was criticized for: (1) translating the realist mind-set from Cold War politics to post-Cold War economics (Ó Tuathail, 1996, p. 239); (2) exaggerating national conflicts and ignoring transnational integration, global networks and interconnectedness (e.g., Ohmae, 1990); and (3) overlooking the remaking and intertwining of geoeconomic/geopolitical discourses and practices relevant to the rebuilding of global capitalism (e.g., SUM, 2013 on the BRIC economies). 
Building on these heuristically powerful critical insights, this article explores the contingent intertwining and enmeshing of geopolitical and geoeconomic discourses and practices with reference to the Chinese case. It highlights how the spread of the 2008 global financial crisis led Chinese intellectuals of statecraft to search for new geoeconomic and geopolitical imaginaries and associated policies in displace some of the crisis tendencies. These imaginaries typically selectively articulate academic theories, policy rhetoric, and media narratives. They often emotionalized hopes and fears that frame, script and spectacularize possible spatial connectivity, links and flows among places, across scales, and over distance (cf. Essex, 2013, p. 3). These sociospatial scripts provide ordering logics, mental models, metaphors/tropes, and discursive devices that shape identities, guide spatial/scalar strategies and orient alliance and coalition building with unintended, uneven, and often contradictory sociospatial effects.

Matthew Sparke (2014) noted that such a theoretical approach to the remaking of sociospatiality requires a 'double vision'2 that focuses on the performative power of geopolitics and geoeconomics and their respective links to fears and hopes (Sparke, 2005). Highlighting the latter aspect, my analysis deepens Sparke's critical perspective by drawing on affect studies (AHMED, 2004; Massumi, 2002) and critical foreign policy analyses (e.g., Booth and Wheeler, 2008). For the affective turn in social sciences, hopes/fears involve individual psychology and emotionally charged discourses (Chaput, 2010, pp. 4-8). For example, in the USA after 9/11, discourses on the 'War on Terrorism' emotionalized and spectacularized geopolitics by stoking security fears and seeking to make the 'war' global (Ahmed, 2015). Similarly, under neoliberalism, the geoeconomic hope of freeing markets on a global scale energizes investors, producers and consumers as they reorient their horizons of action for global capital accumulation and incessant personal gratifications. Similar hopes and fears emerged in the aftermath of the 2008 financial crisis as countries like China started to worry about economic slowdown from its '8-percent growth rate'. Beginning in 2013, this motivated the party leadership to promote hope-based new imaginaries, e.g., 'China Dream', 'New Normal' and the OBOR. 


\section{THE 2008 GLOBAL FINANCIAL CRISIS AND CHINA'S TRIPLE BUBBLES}

China's drive for continued growth was reinforced by its WTO entry in 2001. This facilitated an export boom and China's emergence as a 'global factory' enjoying growing trade surpluses and rising foreign currency reserves. This expansion was constantly threatened by poor labour conditions; overproduction of raw materials and consumer goods; environmental degradation; and the risk of depreciation of its huge foreign reserves. The global financial crisis that erupted in 2008 aggravated these challenges. Exports fell for the first time since 2001, many coastal export firms closed, and unemployment surged. China's investment in US Treasury Bills, which was around USD 1.9 trillion, suffered losses as the dollar depreciated. The US bear market also hurt Chinese banks and fund companies that were heavily invested in Wall Street (Sun and Fu, 2012). In short, this crisis provoked an over-accumulation crisis (Marx, 1998, pp. 237-258, 438--439, 483 and passim) and threatened the party's 'performance legitimacy' (Zhao, 2009), which partly relied on rapid growth in gross domestic product (hereafter GDP).

\section{China's ruling logic of GDPism}

GDPism denotes 'the belief that rapid GDP growth should always be the nation's highest priority because it is the panacea for most national issues and the way to consolidate the government's legitimacy' (Qi, 2010, p. 5). This mode of rule has dominated Chinese policy from the start of its 1978 open door policy. Thereafter the mantra of 'protecting and maintaining an 8\% GDP growth rate' (bao ba) was a mainstay of official rhetoric and a crucial policy benchmark under Premier Deng Xiaoping. It was narrated that $8 \%$ is 'necessary to maintain social stability and provide jobs for tens of millions of new laborers swarming into the country's crowded job market every year' (China Daily, 2009). Party leaders and local government officials reiterated this mantra to sustain the party's goal-based 'performance legitimacy' and their own achievement in GDP terms (Sum, 2013 and 2017).

GDPism operated as powerful discursive apparatus to normalize a regime of truth and guided the party's efforts to manage the economy, politics, and wider society. Its associated political arithmetic required constant concern with threshold maintenance 
and management to secure national stability. It entailed (1) constant comparison with the 8 percent benchmark; (2) distinguishing acceptable and unacceptable policy actions; and (3) regulating conduct by reference to the technical requirements of economic performance. Government units and cadres at national, provincial, city, prefecture and county scales monitored their performance against the benchmark and internalized and applied its logic in their own practices. For example, cadres competed to showcase their urban development icons (e.g., high-speed train lines, airports, and concert halls) and growth rates in bureaucratic beauty contests (Hsing, 2010).

\section{The stimulus package and land- and debt-based accumulation}

Rising unemployment and social unrest following the global financial crisis called into question this GDP logic. In November 2008, the Hu-Wen party leadership sought to re-ignite growth with a four trillion Renminbi (hereafter RMB) stimulus package (equivalent then to 560 billion USD). To facilitate this package, central government relaxed its credit policies and encouraged lending by state-owned banks (SOBs). National ministries and sub-national government units seized this chance to win approval for their pet infrastructural projects. However, to this end, (sub-)national governments had to provide matching funding and did so by intensifying the acquisition of land and leasing land use rights (Wu, 2015, p. 20; see also Lin, 2014; Wu, Xu and Yeh, 2007).

Furthermore, as sub-national authorities were prohibited from raising additional funds without central government approval, they established local government financial vehicles (LGFVs) to collateralize land-use rights and raise money from SOBs and the shadow banking system (Hsu, 2015). ${ }^{3}$ These funding sources included securitized corporate funds, real estate investment trusts, and wealth management products for sale to private and public investors. Sub-national authorities also allied with private developers and auxiliary building industries (e.g., cement, steel, bricks, and heavy machinery). The resulting growth coalitions co-leveraged land and property for lucrative megaprojects and other real estate ventures, increase extra-budgetary government income, and boost individual careers (Sum, 2013; Zhu, 1999). 


\section{Triple Bubbles and Challenges of Over-accumulation, 2010-2015}

These measures, together with the emergence of commercially developed housing since 1994, aggravated the existing 'property bubble'. For example, prices in major cities such as Beijing and Shanghai rose 3.65 and 3.41 times between 2003 and 2013, respectively (Xinahuanet.com 2013). Much of this land- and property-based accumulation was fuelled by debt as: (1) local governments/LGFVs raised loans via collateralization from the shadow banking system; (2) state-owned and private property developers borrowed from SOBs and shadow banking system (Hsu 2015), and (3) households financed real estate purchases via mortgages, savings and leveraging equity. According to National Audit Office data, LGFV debt more than doubled from RMB 4.97 trillion at the end of 2010 (Lu and Sun, 2013, p. 6) to RMB 10.9 trillion in June 2013 (China Daily, 2015a). Additionally, corporate (including stateowned enterprises [SOEs]) debt was reported as $160 \%$ of China's GDP at the end of 2014 (Standard and Poor's, 2015). The total of this debt plus central government and shadow banking borrowing was estimated to have increased from $150 \%$ of GDP in 2008 to $282 \%$ by mid-2014 (Dobbs, Lund, Woetzel and Mutafchieva, 2015).

The second crisis-tendency emerged as nearly half of new debt created in this period went into real estate development and infrastructure projects as well as auxiliary building industries. An infrastructure bubble became evident in empty estates, hardlyused airports, highways to nowhere, and an oversupply of building materials. In 2014, the China Investment Network published a 'ghost town index' that identified around 50 built-but-largely unoccupied cities (Coonan, 2014). Furthermore, reflecting some 7years' worth of unsold housing stock in 2014 , house prices fell nationally by $10 \%$ in 2014 (Kolo, 2014). The slackening property and infrastructure boom aggravated overcapacity problems in related industries such as steel and cement, which produced half of world output in 2014. Annual cement capacity is 2.9bn tonnes; but 2012 demand only reached $2.1 \mathrm{bn}$ (Kolo, 2014). Likewise, the steel industry produced about 804 million tonnes and consumed only 664 million tonnes in 2015 (Lopez, 2016).

These property and infrastructural bubbles spilled over into finance during 2013. Worried that increasing debts and overcapacity were endangering the entire financial system, central government intervened several times to tighten official credit. Shadow 
banking further expanded as an alternative funding source, especially for vulnerable local governments and fragile local-government linked companies. The total local government loan portfolio was estimated at US\$ 9tn between 2010 and 2015 (Rasmus, 2015, p. 149) and this threatened to overwhelm local governments' debtservicing capacity. The situation became worse thanks to growing defaults since 2012: notable cases include Huaxia Bank and CITIC Trust Co. These developments challenged the domestic logic of GDPism (Sum, 2017). In March 2015, the central leadership pre-empted a potential refinancing crisis by issuing a RMB 1 trillion quota to convert maturing high-yield debts into longer-term, lower-cost bonds. While this enabled local governments to save $1.5 \%$ of GDP in debt servicing, it created a vicious cycle of mounting debt, deleveraging, interest rate cuts, and debt swaps.

These developments overlapped with the transfer of authority to the Xi-Li duumvirate, who sought to manage these crisis tendencies by promoting new policy imaginaries and backing them via new means. A prominent example is the eponymous 'Likonomics'. Its two aims were to rebalance the economy from investment to domestic consumption and promote financial liquidity (e.g., issuing bonds to refinance government debt; listing of SOEs on key stock markets, etc.) (Sekine, 2014, p. 5). Concurrently, the State Council and state media encouraged people to invest in the stock markets and thereby share in the 'Chinese Dream'. New online networks linked to the shadow banking system offered instant access to credit for stock-exchange investment and allowed investors to buy on margin. Liquidity surged as over $90 \mathrm{~m}$ retail investors joined the investing herd between 2014 and 2015 and reacted to the latest market and policy rumours. Between June 2014 and June 2015, initial public offerings (IPOs) for SOEs on the Shanghai Composite Index increased 2.5 times (Hu, 2015) and stocks rose around $150 \%$.

That this was unsustainable was shown by a plunge in the same index by $32 \%$ between 8 June and 8 July 2015. This financial asset bubble wiped out USD 3 trillion in (probably fictitious) equity value (Hu, 2015) with estimated losses per investor of RMB 420,000, equivalent to 8 years of an ordinary salary (Lam, 2015). Unsurprisingly, this triggered mounting complaints from retail investors and political panic for the leadership. Although the government intervened to postpone new IPOs and ordered government-controlled funds to purchase stocks and shares to boost prices, 
Likonomics failed to dispel anxieties that the bubble would burst. Paradoxically, then, efforts to stamp out earlier property and infrastructural bubbles spilled over onto the financial one. The interaction of all three bubbles highlighted China's problems of overaccumulation as expressed in excess capacity, inflated property prices, profit squeeze, rising debt, and falling growth rates (Chesnais, 2014, p. 74).

\section{The geoeconomic unease of falling GDP growth rates since late 2015}

China's GDPist target of $8 \%$ growth rate yearly has been in the spotlight with the accumulation of the triple bubbles. They have caused unease at the heart of the leadership, threatening its performance legitimacy, and provoked geoeconomic and geopolitical uncertainties abroad about the global impact of a possible Chinese "hard landing' (Oliver, 2016). Much nervous energy was invested (trans-)nationally in predicting and monitoring the deviation of growth from the new $7 \%$ benchmark set in 2014. Decimal points below $7 \%$ prompted debates about the geoeconomic risks and threats of China's performance both at home and abroad (Magnier, 2015). For example, Premier $\mathrm{Li}$ himself tried to finesse the meaning of falling growth rates in a speech at the opening of the National People's Congress in March 2016. Instead of stating a single number, he mentioned a range between $7 \%$ and $6.5 \%$, creating room for manoeuvre. Despite efforts to manage the triple bubbles, Li's rescue of the financial asset bubble was called into question. He was gradually marginalized in economic decision-making while President $\mathrm{Xi}$ was jostling to control the party-state hierarchy (Lam, 2014).

\section{XI'S 'NEW NORMAL' DISCOURSE: HOPE, CONTAINMENT, RE-PROGRAMMING}

As 'Likonomics' faded Xi's hope-based discourse of a 'new normal' gained traction. He used this more fluid narrative to signal slower but higher-quality growth. The 'new normal' discourse, which was first introduced in 2010 by a giant California-based bond fund, Pacific Investment Management Co. (PIMCO), offered a new post-crisis rhetoric to narrate below-average economic growth. Xi first endorsed it publicly on an inspection tour to Henan Province on 9 May 2014 and an official website hyped this affirmation as 'one of the hallmarks to be engraved in history' (Chinese Executive 
Leadership Academy Jingangshan, 2014). Inspired by PIMCO, Xi selected this fluid discourse to manage public expectations and reassure confidence in face of the bubbles and the slackening Chinese growth.

This 'new normal' discourse condoned a decelerating economy and recalibrated GDPism as the previously benchmarked $8 \%$ annual growth target was replaced by a lower target range. This also helped to subsume old and new policy objectives under a single rubric. This now included financial reforms (e.g., liberalization of interest rates, internationalization of the Renminbi; and greater exchange rate flexibility); increased household consumption; changes in budget laws to allow local governments to issue debt; promotion of high-value-added manufacturing and service industries; introducing mixed ownership for some SOEs to enable them to compete internationally; crackdowns on corruption; improvement of people's well-being; promoting the OBOR geoeconomic initiative; and resetting Sino-American geopolitical relations.

The catchall meaning of the 'new normal', interpreted in neo-Foucauldian terms, suggests a crisis-management discourse oriented to remaking party-state legitimacy despite a decelerating economy. As a wide-ranging discourse, it reorganizes and regularizes official power and helps to accommodate personal ambitions and identities to slower growth via two discursive technologies. First, a technology of containment recalibrates the number order embedded in GDPism, lowering growth expectations for the coming 5 years to $6.5 \%$ and thereby managing expectations. Second, a technology of re-programming strategically recodifies policy discourses to normalize a new governmental rationality (Dean, 1999) that claims that higher-quality growth can compensate for slower growth now and promotes prospect for a brighter future thanks to a mix of revamped and new policy objects and instruments that will become "growth drivers 2.0'. This new hegemonic vision and related accumulation strategy enables party leaders, especially $\mathrm{Xi}$, to reboot their image, marginalize 'Likonomics', create new policy imaginaries that can alter subjectivities and aspirations, and reorganize time, scale, place, space and knowledge in hard times. The OBOR initiative is a linchpin of the 'new normal' because it envisages a new (trans-)regional scale to manage over-accumulation problems. This offers what Harvey (1982) describes as a 'spatial fix' in which new spatial arrangements are created to enable capital (including state capital) to annihilate space with time (Marx, 1973, pp. 320 and 330) and displace 
its debt-laden overcapacity crises abroad through the production of a trans-regional scale of actions (Summers, 2016).

\section{HOW OBOR PRODUCES A TRANS-REGIONAL SCALE AND PROGRAMMES HOPES}

The production of this new spatial scale is mediated, discursively, through the OBOR imaginary. It was co-produced and spectacularized by the party leadership, policy elites from different ministries, planning institutes, think tanks and policy banks that project a better future. Seeking to energize this vision, Xi's 'China Dream' and 'new normal' discourses deployed the historical metaphor of the 'Silk Road' that, under the Han and Tang dynasties, had stretched from China's old capital Xi'an to ancient Rome (Clover and Hornby, 2015). The symbolism of this historical 'trade routes' and 'cultural exchanges' translates the past aura of wealth and cross-border connectivity into the present conjuncture.

\section{Cartographic statecraft to create trans-regional connectivity}

The present hope-based discourses on connectivity are represented and programmed via two spatial metaphors. The 'One Belt' denotes the land-based 'Silk Road Economic Belt' and the 'One Road' is the sea route of the ' $21^{\text {st }}$ Century Maritime Silk Road'. This imaginary was first officially announced by $\mathrm{Xi}$ in a speech at Nazarbavev University in Kazakhstan on 7 September 2013. He announced the maritime component in the Indonesian Parliament on 3 October in the same year. Like most Chinese policies, announcements of new policy concepts by top leaders are subsequently translated into detailed official documents by policy-academic communities (Zheng, 2016). OBOR became official policy when it was incorporated into the Decision of the Central Committee of the Communist Party of China on Some Major Issues Concerning Comprehensively Deepening the Reform in November 2013 and, again, into the State Council's 2014 Report on the Work of the Government. A major document, Visions and Actions on Jointly Building Silk Road Economic Belt and 21st Century Maritime Silk Road, was co-authored by the Ministry of Foreign Affairs, Ministry of Commerce and the National Development and Reform Commission. 
In 2014, following the authorization of the initiative, the official Xinhua Agency published its OBOR map in Chinese and English (see Map 1). This map helped to visibilize and governmentalize the new spatial imaginary (Moore and Perdu, 2014; Pickles, 2004). Such meaning-making devices fuse the spatial hopes and cartographic simplicity in ways that are readily communicable by party leaders, diplomats, official presses, think tanks, consultancy firms, and other agents. Simple cartographic techniques such as territorial lines in primary colours (here, blue and orange) and nodal dots (here, cities/ports) translate the abstract idea of OBOR into a simple visual representation of a connected land-sea mass. The orange line scripted the 'One Belt' as a (trans)-regional land-based historical 'Silk Road' that stretches from China via

\section{Map 1 The Mapping of 'One belt One Road' by Xinhua}

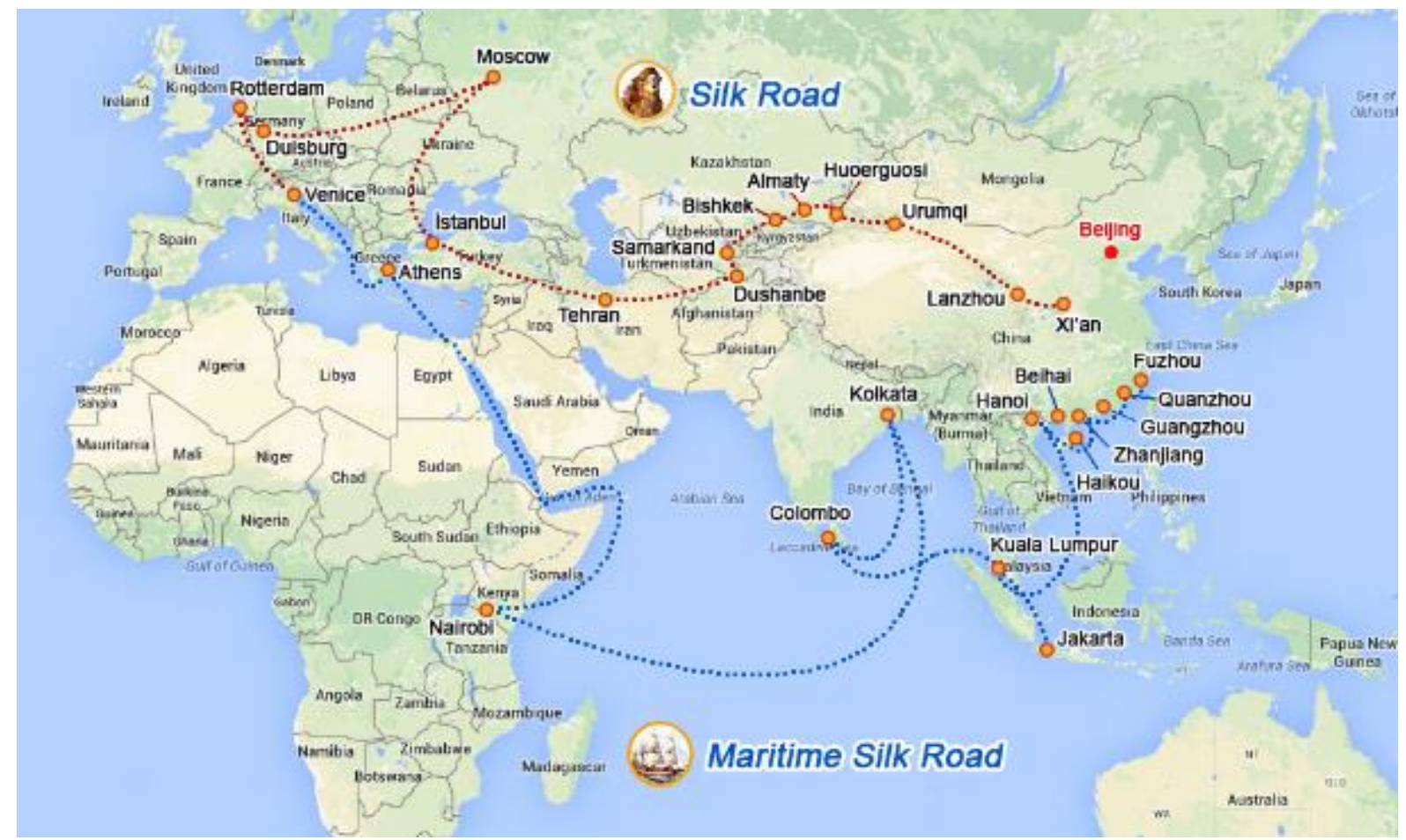

(Source: Originally from Xinhua 2014 and translated into English by Carltonmansfield.com https://www.google.co.uk/search?q=one+belt+one+road\&biw=1093\&bih=515\&source=Inms\&tbm=isch $\underline{\& s a=X \& s q i)}$ 
Central Asia to Turkey, Russia and Continental Europe. Complementing this is the blue line of 'One Road' (or 'Maritime Route'), which revives memories of the Chinese Empire's seafaring prowess and power. The Belt now stretches from China via the Indian Ocean and Africa to the Mediterranean Littoral and Atlantic Seaboard. These two lines guide and naturalize the development of trans-regional connections between urban centres, sea ports, and regions in China, Asia, Europe and Africa that are tasked to perform economic and cultural mutuality that could:

... tap market potential, promote investment and consumption, create demand and job opportunities, enhance people-to-people and cultural exchanges, and mutual learning among the peoples of the relevant countries, and enable them to understand, trust and respect each other and live in harmony peace and prosperity (Xinhua, 2014: 2-3)

\section{Negotiating OBOR identity: geoeconomic and geopolitical metaphors and tropes}

The launch of the OBOR strategy in 2013 was prefigured domestically by two earlier official strategies initiated in the late 1990s under President Jiang. These were the 'Go West' and the 'Go Out' strategies. The former was to reduce the regional imbalances by encouraging investment in trade- and energy-related infrastructure (e.g. roads, hydropower plants, and telecommunications) in China's western provinces, notably Yunnan, and autonomous regions such as Inner Mongolia, Xinjiang, and Tibet. The latter strategy promoted investment abroad, especially by SOEs, to diversify China's foreign reserves, exploit global opportunities, and develop new investment channels (on these strategies, see Wang, 2013). With the onset of the 2008 global financial crisis and the development of China's own triple bubbles, these expansionary dreams and ambitions acquired new geoeconomic and geopolitical meanings as they were articulated with, and modified by, the OBOR imaginary.

First, the 'Go Out' policy was originally justified in 2009 as a 'Chinese Marshall Plan' by Xu Shanda (the former director of China's State Administration of Taxation). He 
presented this plan to the Ministry of Commerce and suggested that China's vast reserves be used to offer loans to developing countries that would then enlist Chinese SOEs to build major infrastructural and construction projects. These roundabout subsidies to Chinese industry would sustain Chinese exports, underpin high GDP growth rates, and reinforce the legitimating ideology of GDPism (on the latter, see Sum, 2013, 2016b). The 'Chinese Marshall Plan' trope triggered geostrategic discourses abroad when tied with OBOR. American think tanks (e.g., Centre for Strategic and International Studies, 2015), foreign relation journalists (e.g., Tiezzi in The Diplomat, 2014) and global business media (e.g., The Wall Street Journal, 2014) suggested that OBOR as a 'Marshall Plan' would enable China to use its economic resources and capacities to secure its foreign as well as economic policy goals. Worried about the risks of translating this American Cold-War security-domination images to the OBOR initiative, Chinese official media and diplomatic circles selectively dismissed the relevance of the 'Marshall Plan' discourse to the OBOR project. For example, Foreign Minister, Wang Yi, speaking on 8 March 2015, stressed that this initiative was 'a product of inclusive cooperation, not a tool of geopolitics, and must not be viewed in the outdated Cold War mentality' (China Daily, 2015b). This interpretation of OBOR allowed China to communicate an inclusive and mutual identity rather than a self-serving and unilateral one (see Table 1).

Narrated as a mutual initiative, connectivity on trade and investment can be improved via (trans-)regional infrastructural construction such as international trunk passageways, high-speed trains, seaways, ports, pipelines, information passageways, fibre-optical lines, low-carbon arrangements, etc. Familiar spatial metaphors such as 'corridors' and 'gateways' (see Table 2) are deployed to imagine possible linkages of these land and sea routes. With the building of mutual cooperation, service networks, industrial clusters, tourist hubs and heritage parks will soon emerge along these traffic routes and then radiate into construction, energy, 


\section{Table 1 Construction of the 'One Belt One Road': Geoeconomic and Geopolitical Tropes and Metaphors}

\begin{tabular}{|c|c|c|}
\hline $\begin{array}{l}\text { Spatialized } \\
\text { Knowledge }\end{array}$ & $\begin{array}{l}\text { Discursive Construction } \\
\text { and Negotiations }\end{array}$ & $\begin{array}{c}\text { Spatial Imaginations (Tropes and } \\
\text { Metaphors) }\end{array}$ \\
\hline $\begin{array}{l}\text { Geoeconomic tropes } \\
\text { Reinvention of: } \\
\text { - 'Go West' and 'Go } \\
\text { Out' Policies } \\
\text { - 'Chinese Marshall } \\
\text { Plan' } \\
\text { Tropes of mutuality and } \\
\text { inclusiveness }\end{array}$ & $\begin{array}{l}\text { Extension of the 'Go West' } \\
\text { and 'Go Out' Policies in the } \\
\text { contexts of China's triple } \\
\text { crises and the Xi's 'China } \\
\text { Dream' and 'New Normal' } \\
\text { Negotiation of OBOR's } \\
\text { identity with reference to US } \\
\text { Marshall Plan } \\
\text { Focus on building } \\
\text { infrastructural-oriented } \\
\text { networks based on } \\
\text { 'mutuality' and 'connectivity' } \\
\text { (not domination as in the } \\
\text { Cold War Marshall Plan) }\end{array}$ & $\begin{array}{l}\text { Historical metaphor of the 'Silk Road' } \\
\text { The use of cartographic statecraft such as } \\
\text { maps, territorial lines and dots } \\
\text { Joining these lines and dots to create the } \\
\text { OBOR space to the west of China } \\
\text { Mapping the 'One Road' and 'One Belt' as } \\
\text { a land-sea mass that covers China, Asia, } \\
\text { the Middle East, Europe and Africa } \\
\text { Constructing mutuality and connectivity via } \\
\text { the building of (trans-)regional } \\
\text { infrastructure such as highways and ports } \\
\text { Using geographical planning metaphors } \\
\text { such as corridors and gateways to frame } \\
\text { geographical connectivity (see Table 2) }\end{array}$ \\
\hline $\begin{array}{l}\text { Geopolitical tropes } \\
\text { 'Eurasia' imaginary } \\
\text { Trope of Mackinder's } \\
\text { 'Heartland theory' } \\
\text { Trope of 'community of } \\
\text { common destiny' }\end{array}$ & $\begin{array}{l}\text { Construction of 'West Pivot' } \\
\text { in the contexts of China's } \\
\text { more assertive 'Peaceful } \\
\text { Rise' } \\
\text { 'Pivot West' and the 'Eurasia' } \\
\text { imaginary as offering } \\
\text { opportunities } \\
\text { Building community of } \\
\text { common destiny with } \\
\text { Central Asia, EU and Russia } \\
\text { via infrastructure investment }\end{array}$ & $\begin{array}{l}\text { Metaphors of mutuality and cooperation } \\
\text { (and not imperial domination) } \\
\text { Denouncing and distancing from } \\
\text { Mackinder's space-conquering analogy in } \\
\text { framing OBOR } \\
\text { Disarticulating OBOR from Mackinder's } \\
\text { theory and rearticulating the 'Eurasia' } \\
\text { imaginary in mutual geoeconomic and } \\
\text { geostrategic terms }\end{array}$ \\
\hline
\end{tabular}

(Source: Author's own compilation)

trade, production, finance, communication, logistics, and tourism. This project is mapped to cover 65 countries with a total population of 4.4 billion people with a 
disposable income of around US\$21 trillion; it also accounts for $63 \%$ and $29 \%$ of global capacity respectively for the belt and road components (Wang, 2015, pp. 9498).

Table 2 Planning Metaphors Used in the One Belt One Road Imaginary

\begin{tabular}{|c|c|}
\hline Metaphors & Examples \\
\hline Corridors & $\begin{array}{l}\text { - China-Pakistan Economic Corridor (see later) } \\
\text { - } \quad \text { New Eurasian Land Bridge } \\
\text { - China-Central-Asia-West-Asia Corridor } \\
\text { - Bangladesh-China-India-Myanmar Corridor } \\
\text { - Indochina Peninsula Corridor }\end{array}$ \\
\hline Gateways & $\begin{array}{l}\text { - Chongqing as the 'logistic gateway' that connect } \\
\text { western China to Germany by the Yu-Xin-Ou Railway } \\
\text { - Khorgos Gateway on the Kazakh-Chinese border } \\
\text { - Manzhouli as gateway between China, Russia and } \\
\text { Mongolia }\end{array}$ \\
\hline
\end{tabular}

(Source: Author's own compilation)

Second, the building of this geoeconomic imaginary is deeply intertwined with China's reorientation of its foreign policy rhetoric from promoting 'peaceful rise and harmonious world' (Lam, 2009; Shirk, 2008) to 'peaceful development and Chinese Dream' destinies/destined to build a 'new type of great power relations' (Hartig, 2016, p. 2228; Yi, 2014). In response to the Obama Administration's policy, announced in 2011, to 'Pivot towards the Asia-Pacific, Wang Ji-Si (2013), a leading Chinese expert, proposed in late 2012 to avoid confrontation with the USA by undertaking a 'March Westward' strategy (Clarke, 2016, p. 19). This proposal and its subsequent reinvention of an OBOR-related Eurasia possibility were not without its analogous comparison with a classical geopolitical theme in $19^{\text {th }}$ and early $20^{\text {th }}$ century. 
Specifically, one of the 'fathers of geopolitics' and a fervent champion of the British Empire, Halford Mackinder, formulated his Eurasian 'Heartland Thesis' in 1904 (Mackinder, 1904). By linking power to space, he suggested that the 'Eurasian' landmass is the most advantageous geopolitical location for military and industrial development. Countries that dominate this pivotal 'heartland' would possess the geopolitical and geoeconomic potentials to dominate the world. Similar themes were proposed in German geopolitical analyses (e.g., Haushofer, 1941; Ratzel, 1940, 1987), although these fell from favour because of their association with Nazism. In contrast, Mackinder's heartland thesis has proved a popular geopolitical metaphor. It has provided a theoretical rationale for strategies of territorial-expansion and imperial governmental technologies (Morozova, 2014). It is also counter-posed to the Eurasian heartland's main rival - the maritime sphere that includes Western Europe, North America, Maritime East Asia, Australia, and the Mediterranean littoral.

Unsurprisingly, China's OBOR project to create a contiguous Eurasian space by leveraging geoeconomic networks has been compared to Mackinder's analysis and its geostrategic implications. New fear-based geopolitical discourses emerged in the international arena. For example, Clarke, writing for The Diplomat, saw OBOR as 'a realization of Mackinder's vision' (2015). The Pacific Perspective (2017) interpreted it as an exercise of Chinese 'informal imperial power'. Such readings interpret OBOR as facilitating the creation of a Sinocentric Eurasian system that would be based on infrastructure rather than military conquest and that would enable China to build a land empire. Interestingly, the One Road can be seen as its Maritime equivalent. Worried about the connotations of transferring Mackinder's space-conquering image to OBOR, the Chinese authorities have rejected this analogy. For example, Liu Xiaoming, the Chinese ambassador to Britain, denied that the OBOR initiative confirmed Mackinder's thesis (2015). Apart from attempts to distance OBOR imaginary from Mackinder's geopolitical imaginary, academics and policy-makers are reframing it as global 'gift' based on cooperation and inclusive globalization (Wang, 2015, pp. 103-107; see also Liu and Dunford, 2016). Tropes of win-win and 'community of common destiny' based on flows and linkages are deployed to brand/market OBOR's identity (see Table 1). 


\section{Translating OBOR into policy objects}

The ordering logic of these geopolitical-geoeconomic statecraft and tropes (and their contested negotiations) have shaped policy and consultancy discourses since OBOR's official inception in September 2013. Official Chinese channels, commissions, business/investment consultancies, think tanks and diplomatic circles are all energetically engaged in selectively co-producing, circulating, and normalizing OBOR as a set of policy objects and defended it against criticisms. On the promotional side, the OBOR identity and creation of a trans-regional land-sea mass are spectacularized as 'opportunities' to build a win-win, infrastructure-oriented community. China Daily, an official organ, hailed this on 6 May 2015 as the 'second biggest geographical discovery in human history after Mackinder's breakthrough'. The re-envisioning of this land-sea mass was praised as a re-awakening of 'Eurasia' from its 500-year slumber that would facilitate China's return to centre stage. This imaginary was concretized through vision statements and a dedicated web-based platform on policies and OBOR news and activities, namely: http://www.xinhuanet.com/english/special/silkroad/index.htm. This euphoria was echoed by some business-consultancy sources that praised it as a 'brilliant plan' (CLSA, 2015) that could 'export China's [infrastructural] development blueprint to the world' (Swain, 2014, p. 8) and could 'stimulate world trade' (Tan, 2015). The World Pensions Council has even seen it as a long-awaited response to a massive infrastructure gap created by neoliberal neglect of this key condition for world trade.

There were also critical discourses, however, especially in diplomatic circles. Contributors to The Diplomat, which is linked to the Centre for Strategic and International Studies (an influential American think tank), commented that the project was 'China-centred', 'at risk of failure' (Rudolf, 2015) and 'a geopolitical 'gamble' that competed with the US for allies (Yale, 2015). India's Ministry of External Affairs saw it as a 'national Chinese initiative' that should be opened to multilateral consultation (Madan, 2016). One Taiwan source even interpreted this initiative as China's endeavour to 'dominate Eurasia without a war' (Lin, 2015). Nonetheless, in providing a policy focus, the OBOR imaginary is making the Belt-Road project more visible and encouraging actors to calculate how it could create 'mutual benefit' and 'win-win' outcomes based on 'cooperation' and 'trust and respect' around cooperation and 
connectivity. This fits with official discourse about OBOR's potential to align different local, regional, national, and trans-regional strategies and interests. These claims are staged and repeated in national and (trans-)regional official speeches, public forums, (e.g., Belt and Road Forum 2017 in Beijing), cooperation intentions (e.g., the EU's Juncker plan, named after Jean-Claude Juncker when he was the European Commission President) and state visits (e.g., Xi's visit to Central and Eastern Europe in June 2016). By 2016, major think tanks, investment consultancies and the international organizations have produced their own knowledge products in the form of promotional/assessment reports and blogs on this scheme (see Table 3).

Table 3 Knowledge Production and the Making of One Belt One Road as a Policy Object

\begin{tabular}{|c|c|c|}
\hline $\begin{array}{l}\text { Type of } \\
\text { knowledge- } \\
\text { Producing } \\
\text { Institution }\end{array}$ & Example(s) & Title and Year of Report \\
\hline \multirow[t]{5}{*}{ Think tanks } & Chatham House (UK) & $\begin{array}{l}\text { Tim Summers, What Exactly is 'One Belt } \\
\text { One Road'? (2015) }\end{array}$ \\
\hline & $\begin{array}{l}\text { Konrad Adenauer } \\
\text { Stiftung (Germany) }\end{array}$ & $\begin{array}{l}\text { Patrick Bessler, China's "New Silk Road": } \\
\text { Focus on Central Asia (2015) }\end{array}$ \\
\hline & $\begin{array}{l}\text { Brookings Institute } \\
\text { (USA) }\end{array}$ & $\begin{array}{l}\text { David Dollar, China's Rise as a Regional } \\
\text { and Global Power: The AllB and the 'One } \\
\text { Belt, One Road' (2015) }\end{array}$ \\
\hline & $\begin{array}{l}\text { Lowy Institute } \\
\text { (Australia) }\end{array}$ & $\begin{array}{l}\text { Peter Cai. Understanding China's One Belt } \\
\text { One Road Initiative (2017) }\end{array}$ \\
\hline & $\begin{array}{l}\text { S. Rajaratnam School } \\
\text { of International } \\
\text { Studies (Singapore) }\end{array}$ & $\begin{array}{l}\text { Alessandro Arduino, China's One Belt One } \\
\text { Road: Has the European Union Missed the } \\
\text { Train? (2016) }\end{array}$ \\
\hline \multirow{2}{*}{$\begin{array}{l}\text { International/ } \\
\text { Regional } \\
\text { Organizations }\end{array}$} & World Bank & China's One Belt One Road Initiative (2015) \\
\hline & European Parliament & $\begin{array}{l}\text { One Belt One Road (OBOR): China's } \\
\text { Regional Integration Initiative (July 2016) }\end{array}$ \\
\hline $\begin{array}{l}\text { Investment } \\
\text { Consultancies }\end{array}$ & $\begin{array}{l}\text { PriceWaterhouse } \\
\text { Cooper }\end{array}$ & $\begin{array}{l}\text { China's New Silk Road: the Long and } \\
\text { Winding Road (2016) }\end{array}$ \\
\hline
\end{tabular}




\begin{tabular}{|l|l|l|}
\hline McKinsey \& Co. & $\begin{array}{l}\text { Gll Beijing: Navigating One Belt One Road } \\
(2015)\end{array}$ \\
$\begin{array}{l}\text { BNP Paribas } \\
\text { Investment Partners }\end{array}$ & $\begin{array}{l}\text { One Belt One Road: One Stone Kills Three } \\
\text { Birds (2015) }\end{array}$ \\
\hline
\end{tabular}

(Source: Author's own compilation based on web research)

\section{INFRASTRUCTURE AS A MODE OF GROWTH AND LOAN-DEBT INVESTMENT}

These negotiated ensembles of hope-based knowledge on OBOR not only shape subjectivities and their relations across time-space but also contribute to building institutions and interest-related coalitions centred upon infrastructure building, financing and security. As part of its 'Go Out' strategy, a China-oriented infrastructural mode of growth (Hildyard, 2016, p. 26) with a (trans-)regional spatial reach is emerging in the shadow of global capitalism. It helps to manage China's triple bubbles by prolonging accumulation in two main ways: (1) mobilizing what amounts to a new stimulus package with the potential to export infrastructure-related excess capacity (e.g., building materials, technological know-how, manpower, etc.) as well as extend global supply chains and enhance geopolitical anchorages; and (2) deploying old and developing new loan-debt investment and practices to finance OBOR projects. Three inter-related configurations are being developed to govern OBOR-related accumulation. They concern the production of infra- and info-structures; finance; and security respectively. Each involves various ministries, commissions, SOEs, SOBs, provincial/local governments, and educational/training/security setups in various partnerships and compromise with private and regional/global institutions that govern relations among territories, places, scales, and networks.

\section{Three OBOR governance configurations: production, finance and security}

The first configuration involves the governance of the export-oriented production arrangements that help alleviate China's overcapacities in infrastructural building material and related engineering, technological know-how/standards and workforce. The partners in governance comprise a panoply of Chinese ministries, planning 
commissions, embassies, provincial/city governments, infrastructure-focused SOEs (e.g., China State Construction Engineering Corporation Limited), private firms (e.g., Huawei in telecommunications) and local partners (see Table 4). They are building infrastructural/energy projects (e.g., highways, port construction and operation, highspeed trains, information highways, surveillance systems, power plants, logistic centres, agricultural estates, entertainment resorts, etc.) that provide them with contracts to absorb China's excess capacities; and they are also extending their global production, trade, and resource chains. There are many such projects. I will illustrate some key features below from the flagship project of China-Pakistan Economic Corridor (CPEC).

\section{Table 4 Production Configuration of the 'One Belt One Road'}

\begin{tabular}{|c|c|c|c|}
\hline $\begin{array}{l}\text { Governance } \\
\text { Configuration }\end{array}$ & $\begin{array}{l}\text { Nature of the } \\
\text { Configuration }\end{array}$ & $\begin{array}{l}\text { Some Main National } \\
\text { Institutions Involved }\end{array}$ & $\begin{array}{c}\text { Some Private and } \\
\text { Global Institutions } \\
\text { Involved }\end{array}$ \\
\hline $\begin{array}{l}\text { Production- } \\
\text { related } \\
\text { infra- and info- } \\
\text { structural } \\
\text { configuration } \\
\text { that relieves } \\
\text { and displaces } \\
\text { domestic } \\
\text { overcapacities } \\
\text { by redirecting } \\
\text { them abroad }\end{array}$ & $\begin{array}{l}\text { Infrastructural } \\
\text { construction abroad } \\
\text { - Highways, bridges, } \\
\text { ports, harbours, } \\
\text { airports, power } \\
\text { generation, real estate, } \\
\text { etc. } \\
\\
\text { Engineering and } \\
\text { procurement } \\
\\
\text { Building material and } \\
\text { know-how } \\
\text { - Steel, iron, cement, } \\
\text { sheet glass, fibre } \\
\text { optics, etc. } \\
\text { High-speed and normal- } \\
\text { speed railway } \\
\text { construction } \\
\text { Terrestrial } \\
\text { telecommunication links } \\
\text { - information technology } \\
\text { (IT) equipment and } \\
\text { telecommunication } \\
\text { system (e.g., fibre optic } \\
\text { cables, , broadband, }\end{array}$ & $\begin{array}{l}\text { Highways, bridges and real } \\
\text { estate } \\
\text { - Ministries of Construction } \\
\text { and Transport } \\
\text { - China State Construction } \\
\text { Engineering Corporation } \\
\text { Ltd. } \\
\text { - China Communication } \\
\text { Construction Co. Ltd. } \\
\text { Engineering services } \\
\text { - China National Materials } \\
\text { - // China Machinery } \\
\text { Engineering Corporation } \\
\text { Steel } \\
\text { Anshan Iron and Steel } \\
\text { Group } \\
\\
\text { Railway engineering and } \\
\text { manufacturers } \\
\text { - China Railway Rolling } \\
\text { Stock Corporation } \\
\text { Ministry of Communication } \\
\text { Ministry of Commerce }\end{array}$ & $\begin{array}{l}\text { ICT products, services } \\
\text { and solutions } \\
\text { - Huawei } \\
\text { Technologies } \\
\text { - ZTE } \\
\text { - China Mobile }\end{array}$ \\
\hline
\end{tabular}




\begin{tabular}{|l|l|l|l|}
\hline $\begin{array}{l}\text { logistic networks, e- } \\
\text { commerce) } \\
\text { Infrastructure operation }\end{array}$ & $\begin{array}{l}\text { E-Commerce } \\
\text { - Alibaba } \\
\text { - Tencent }\end{array}$ \\
& $\begin{array}{l}\text { Port operation and cargo } \\
\text { transportation } \\
\text { China Merchants } \\
\text { Holdings International } \\
\text { Co. Ltd. }\end{array}$ & \\
\hline
\end{tabular}

(Source: Author's own compilation)

This production configuration is supported by a second governance configuration, focused on finance. Efforts were stepped up to develop what amounted to another round of stimulus package based on loan-debt investment to absorb excess capacities and acquire strategic resources/influence. The ultimate aim is to internationalize the use of Renminbi (see Table 5). According to Xinhua Finance (2015), the OBOR initiative requires at least US\$800 billion annually between 2015 and 2025. Most projects are led by infrastructural and energy SOEs funded from a fusion of trade finance, loans, grants, and credits issued by policy banks (e.g., China Development Bank), SOBs and the New Silk Road Infrastructure Fund (see Table 6). Other investment comes from provincial governments/banks, in partnership with SOEs, which provide loans to export excess capacities and acquire foreign assets. Given the huge amount of funds required, it also involves turning infrastructure into an asset class and attracting other investment through: (1) (un-)listed funds and bond issuances on major stock exchanges (e.g., OBOR Bond in Singapore); (2) private-public partnerships; and (3) three new (inter-)governmental funds, etc. (see Tables 5 and 6).

\section{Table 5 Financial Configuration of the 'One Belt One Road'}

\begin{tabular}{|c|c|c|c|}
\hline $\begin{array}{l}\text { Governance } \\
\text { Configuration }\end{array}$ & Nature of the Configuration & $\begin{array}{l}\text { Some Main National } \\
\text { Institutions Involved }\end{array}$ & $\begin{array}{c}\text { Some Private and } \\
\text { Global Institutions } \\
\text { Involved }\end{array}$ \\
\hline $\begin{array}{l}\text { Financial } \\
\text { configuration } \\
\text { that } \\
\text { mobilizes new } \\
\text { funding to fill } \\
\text { the funding } \\
\text { gaps and } \\
\text { relieve the } \\
\text { debt burden }\end{array}$ & $\begin{array}{l}\text { Outward direct investment } \\
\text { Grants by policy banks } \\
\text { Loans from policy banks and } \\
\text { SOBs } \\
\text { - Funding for infrastructural } \\
\text { investment in ports, roads, rail } \\
\text { and resources }\end{array}$ & $\begin{array}{l}\text { - Ministry of Commerce } \\
\text { - SOEs (after mergers } \\
\text { and acquisitions) } \\
\text { - State Administration } \\
\text { of Foreign Exchange } \\
\text { - Policy banks (e.g., } \\
\text { Bank of China, China } \\
\text { Development Bank, } \\
\text { China Ex-Im Bank) }\end{array}$ & - Private firms \\
\hline
\end{tabular}




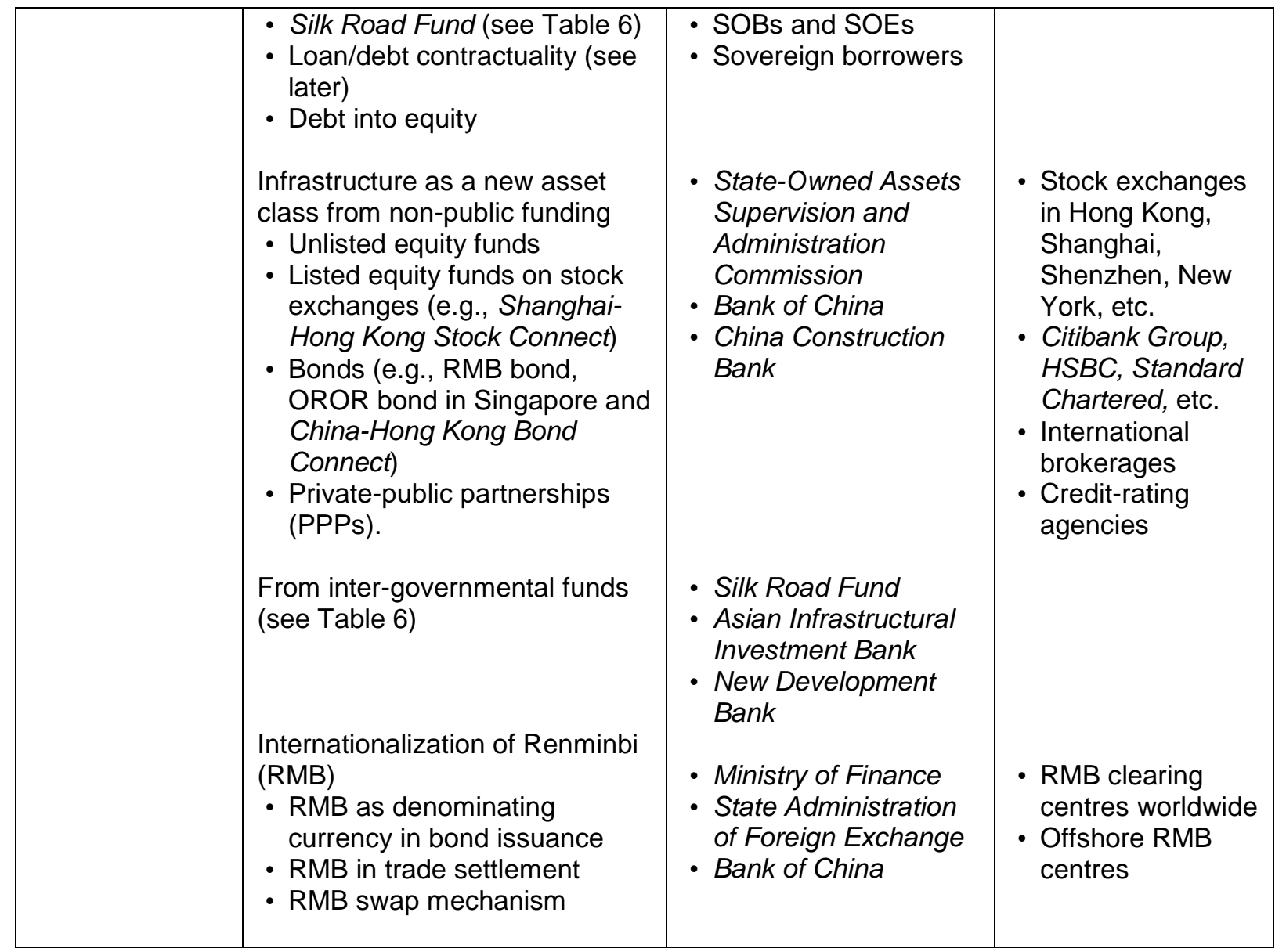

(Source: Author's own compilation)

Three major financial institutions have been established: The Silk Road Fund, the New Development Bank, and the Asian Infrastructure Investment Bank (AllB) (see Table 6). Whilst the first is state-owned, the second is more BRICS-driven, and the third is even more multilateral. The AlIB was established in October 2014 with 77 countries signing up by May 2017. Its authorized capital is US\$100 billion with half from China. As an emergent multilateral infrastructural bank, it works with International Financial Corporation (member of the World Bank) and its regional counterparts (e.g., Asian Development Bank). It also mobilizes and co-ordinate inter-governmental support to raise semi-commercialized loans from sovereign funds, pension/insurance funds, etc. To this end, public-private partnerships (PPPs) as a financing method are widely discussed and promoted in China to enable the sharing of risks and returns for the private sector (Jin, 2015, p. 1) (Table 5). 
Table 6: A Facet of the Financial Configuration: Three New Financial Institutions

\begin{tabular}{|c|c|c|c|c|}
\hline Name & $\begin{array}{l}\text { Year and } \\
\text { States } \\
\text { Involved }\end{array}$ & $\begin{array}{c}\text { Amount } \\
\text { (US\$) }\end{array}$ & Institutions & Nature \\
\hline $\begin{array}{l}\text { Silk Road } \\
\text { Infrastructure } \\
\text { Fund }\end{array}$ & $\begin{array}{l}\text { December } \\
2014 \\
\text { China }\end{array}$ & $\begin{array}{l}\text { US\$ } \$ 40 \\
\text { billion }\end{array}$ & $\begin{array}{l}\text { State-owned } \\
\text { by China } \\
\text { Investment } \\
\text { Corporation } \\
\\
\text { Loans issued } \\
\text { by China } \\
\text { Development } \\
\text { Bank, China } \\
\text { Ex-Im Bank }\end{array}$ & $\begin{array}{l}\text { - Earmarked for OBOR } \\
\text { infrastructural projects } \\
\text { - An initial capital of US } \$ 10 \text { billion } \\
\text { - Another US } \$ 6.5 \text { billion from } \\
\text { China's foreign exchange } \\
\text { reserves } \\
\text { - Managed as China's sovereign } \\
\text { wealth fund }\end{array}$ \\
\hline $\begin{array}{l}\text { Asian } \\
\text { Infrastructure } \\
\text { Investment } \\
\text { Bank }\end{array}$ & $\begin{array}{l}\text { Proposed } \\
\text { in October } \\
2014 \text { and in } \\
\text { operation in } \\
2016 \\
\\
77 \text { states } \\
\text { (by May } \\
2017 \text { ) }\end{array}$ & $\begin{array}{l}\text { Total } \\
\text { capital of } \\
\text { US\$ } 100 \\
\text { billion } \\
\text { China's } \\
\text { subscribed } \\
\text { US\$ 50 } \\
\text { billion } \\
\text { Paid-in } \\
\text { capital } \\
\text { around } 20 \\
\text { percent }\end{array}$ & $\begin{array}{l}\text { Beijing-based } \\
\text { inter- } \\
\text { governmental } \\
\text { development } \\
\text { financing } \\
\text { institution }\end{array}$ & $\begin{array}{l}\text { - Funding for infrastructures that } \\
\text { are not under sovereign credit } \\
\text { - Promotion of PPP method in } \\
\text { expanding funding (e.g., pension } \\
\text { funds) } \\
\text { - Managing projects by sharing } \\
\text { risks and returns with the private } \\
\text { sector } \\
\text { - Enforcement of contracts } \\
\text { (including user charges) }\end{array}$ \\
\hline $\begin{array}{l}\text { New } \\
\text { Development } \\
\text { Bank (former } \\
\text { BRICS } \\
\text { Development } \\
\text { Bank }\end{array}$ & July 2014 & $\begin{array}{l}\text { US } \$ 50 \\
\text { billion (10 } \\
\text { billion from } \\
\text { China) }\end{array}$ & $\begin{array}{l}\text { BRICS } \\
\text { countries } \\
\text { (Brazil, } \\
\text { Russia, India, } \\
\text { China and } \\
\text { South Africa) }\end{array}$ & $\begin{array}{l}\text { - Infrastructural projects in BRICS } \\
\text { as priority } \\
\text { - Each country select its own } \\
\text { infrastructural projects to be } \\
\text { developed }\end{array}$ \\
\hline
\end{tabular}

Note: BRICS = Brazil, Russia, India, China and South Africa

(Source: Author's own compilation)

Third, contrary to the financial arrangement, the place-based production configuration faces continuous security challenges, especially in some divided or contested territories along the Belt. For example, the flagship CPEC project, which builds infrastructural links between Kashgar (in China's Xinjiang Province) and Pakistan's port in Gwadar, passes through Balochistan for access to the Arabian Sea and bypasses the Malacca Strait. However, Balochistan has been affected over decades by 
nationalist-separatist struggles against the Pakistan army. Worried that the CPEC is another attempt to grab Baloch's resources and dispossess local people (e.g., fisherfolk in Gwadar port and ordinary citizens from their homes due to land development) (Pal, 2017, p. 4), separatists are attacking oil tankers, gas pipelines and Chinese workers. Similar attacks (e.g., Juba in Sudan) and less violent security issues (e.g., labour disputes and thefts) occur elsewhere (e.g., the dock strike in Piraeus, Greece). All these incidents indicate the need to 'go out' safely by enhancing security protection and intensifying anti-terrorist policy. In response, a new security configuration is emerging with Chinese private security firms/operatives, global providers and local counterparts cooperate/jostle to guard Chinese pipelines, railways, power plants and workers in divided or contested territories (Goh, Martina and Shepherd, 2017). Where the military is already active, governments may make forces and intelligence available. For example, in 2017, the Pakistan state has created a 12,000-strong special security division to defend the CPEC project (Rifaat and Maini, 2016, p. 14) (see Table 7).

Table 7 Security Configuration of 'One Belt One Road'

\begin{tabular}{|c|c|c|c|}
\hline $\begin{array}{l}\text { Governance } \\
\text { Configuration }\end{array}$ & $\begin{array}{l}\text { Nature of the } \\
\text { Configuration }\end{array}$ & $\begin{array}{l}\text { Some Main National } \\
\text { Institutions Involved }\end{array}$ & $\begin{array}{c}\text { Some Private and } \\
\text { Global Institutions } \\
\text { Involved }\end{array}$ \\
\hline $\begin{array}{l}\text { Security } \\
\text { configuration } \\
\text { that protects } \\
\text { infrastructure, } \\
\text { resources and } \\
\text { labour }\end{array}$ & $\begin{array}{l}\text { Provision of security } \\
\text { services with support from } \\
\text { local teams } \\
\text { Provision of security } \\
\text { training by global security } \\
\text { firms }\end{array}$ & $\begin{array}{l}\text { - Chinese security firms } \\
\text { (e.g., Dewei Security) } \\
\text { run by personnel with } \\
\text { military backgrounds } \\
\text { - In Pakistan, special army } \\
\text { division to ensure } \\
\text { protection } \\
\text { - China-Pakistan land and } \\
\text { sea cooperation to } \\
\text { mitigate CPEC-related } \\
\text { risks }\end{array}$ & $\begin{array}{l}\text { - Global security firms } \\
\text { such as Frontier } \\
\text { Security Group } \\
\text { (founded by the co- } \\
\text { founder of } \\
\text { Blackwater) provide } \\
\text { security training } \\
\text { services to OBOR- } \\
\text { related projects in } \\
\text { Southeast Asia }\end{array}$ \\
\hline
\end{tabular}

(Source: Author's own compilation) 


\section{OBOR's emerging uneven and contradictory multi-spatial development}

These emerging configurations are developing and realigning production, finance and security under a more ambitious, multi-spatial round of loan-debt investment. Their activities are mediated transnationally by China's SOEs/SOBs, provincial governments, private firms, signatory (sub-)national governments, national/multilateral development funds, development agencies, international/regional organizations, investment consultancies, commercial banks, insurers, stock exchanges, security firms, and military agencies across territories, places, scales, and networks. Examples of multi-scalar aspects of the project include how OBOR is being appropriated by local and regional governments in China to deal with their own issues of loss of competitiveness, declining population and inequalities. In China's northeast region (Dongbei), which has no historical relation with the Silk Road, these local/regional governments are joining the OBOR bonanza thanks to the Chang-Ji-Tu project. This connects efforts in Hunchun in China's Juli Province to build special economic zones to link with North Korea that can then be articulated to OBOR's China-MongoliaRussia-Economic Corridor. Likewise, at the national scale, since the inauguration of the President Moon in South Korea in 2017, the government has formulated the New Northern Policy to identify new economic opportunities (e.g., building railways and seaports) across the Arctic route. South Korea would thereby engage both with China's OBOR and Russia's Eurasian Economic Union projects to experiment with new scalar connections. ${ }^{4}$

These emerging imaginaries and associated policies and projects, with their trial-anderror multi-spatial (especially multi-scalar) modes of governance, provide the basis for new infrastructural mode of growth that operates in the shadow of global capitalism and thus must address diverse geopolitical challenges (Jessop and Sum, 2018). Here we find new projects (e.g., South Korea's New Northern Policy in preceding paragraph) as well as more established ones (e.g., CPEC discussed above) contributing to this mode of growth. Nonetheless, as this China-centred mode develops and absorbs more production and financial capital, it intensifies and spreads

at least three kinds of contradictory and antagonistic development. First, on the production front, the drive to export China's overcapacity problems abroad engender 
struggles at accumulation by dispossession (Harvey, 2009) as the pursuit of OBOR projects displaces local workers, economic groups and communities through job, land and resource grabs that have serious distributive, environmental and security implications. As the CPEC case indicates, OBOR was narrated as a growth projects; but it mainly benefits large corporate-military concerns at the expense of domestic small- and medium-sized industries (Chakraborty, 2017). Other issues include labour and ethnic conflicts between Chinese management and local labour, the destruction of protected forests and traditional fishing communities, and separatist attacks (Dawn, 2017; UNESCAP, 2017) (see above).

Second, financially, the push to export overcapacities and develop connectivity has produced contradictory developments within China. Investment in OBOR has become a pervasive theme for China's national economic planning agency, subnational governments, city regions, universities and many other authorities and institutions (Cai, 2017). For example, Chongqing Municipality narrates itself as a 'megacity' and focuses on creating the capacities and facilities to become an OBOR free trade zone. Zhejiang Province concentrates on developing maritime services. But such OBORrelated projects intensify China's overcapacity problems and some new funding is even used to service old debts, thereby deepening the already heavily indebted (sub)national governments rather than contributing towards investments.

Third, depending on transnational networking and the governance mechanisms of the receiving countries, projects are not always transparent or evaluated fully in risk assessment terms. In the main, China's OBOR loans, contrary to Washington Consensus type IMF-World Bank loans, which operate according to multilateral 'structural-adjustment' and 'good governance' conditionalities (Babb, 2012), rely more on 'loan-debt contractuality'. ${ }^{5}$ This contractuality rests on tailor-made bilateral (some multilateral) loan framework agreements made with SOEs/SOBs, China Construction Bank, the Silk Road Fund, etc. As legal-disciplinary techniques, contracts regulate and normalize relevant financial and material relations by stipulating: (1) the amount, purpose, duration and concentration of loans; (2) manner of repayment, loan ceilings and the nature of credit lines; (3) the duration of grace periods and subsequent interest rate arrangements; (4) the sovereign share of the loans and maturity periods; (5) the amount and manner of private investment; (6) the exchange rate and loan proportions 
denominated in US dollar, Renminbi, and other currencies; (7) the extent and use of Chinese resources and manpower; (8) provisions for use/control of the infrastructure; (9) guarantees and events of default; (10) arbitration mechanisms; and so on (Zhang and Millar, 2017). Should this contractual relationship end in defaults, the loan-debt obligations allow China to renegotiate the terms, collateralize the debt and claim assets/resources by converting debt into equity.

Sri Lanka is a good example of some aspects of this loan-debt contractuality. Its government owed China a total of USD 8 billion in 2017 including USD 301 million for building the Hambantota Port. China provides a 4-year grace period but charges 6.3 percent for the port loan, which compares with the World Bank interest rates of between 0.25 to 3 percent for similar projects (Graceffo, 2017). In addition, with the slackening of the Sri Lankan economy and declining demand for its port services, its national government has racked up losses of USD 300 million and a debt-servicing cost of USD 50 million in 2017. Following the governance logic of loan-debt contractuality, China, instead of rescheduling the debt, offered another USD 1.1 million to convert this debt into equity. This power asymmetry has enabled China Merchant Port Holdings (International) Co. Ltd. to acquire 70 percent of the Hambantota port, including a 99-year lease for a surrounding industrial zone (Dutta, 2017). The extension and unevenness of these loan-debt arrangements are resisted by diverse Sri Lankan groups because of corruption charges, the loss of land and local livelihood around the port area as well as geopolitical worries of China gaining maritime access in the Indian Ocean competing for influence, trade and energy.

Similar geoeconomic and geopolitical challenges related to bilateral loan-debt contractuality are emerging in Pakistan, Cambodia, Myanmar, Kenya, Ethiopia, Malaysia, etc. (Chaudhury, 2017; Sheehan, 2017; Venkatachalam, 2017). Chellaney described its potential predatory effects as 'debt trap diplomacy' that put financiallyfragile partners in debt under increasing Chinese leverage (2017) via a virtual 'bait and switch' manoeuvre. Seen in more political economy terms, China, in relieving its own triple bubbles via OBOR, is intensifying its own debt burdens partly because of the sheer size, security threats and weak risk management tools used in assessing OBOR projects. Looking beyond China, it is spreading the debt burden abroad as the loan- 
debt investment adds to the vicious debt cycles of some developing countries and may compel them to make geoeconomic/geopolitical concessions.

This emerging transnational social relation is raising concerns for capital and states alike. On 21 September 2017, Standard and Poor's Global Ratings, worried about the increasing debt load in China, downgraded its long-term sovereign ratings form 'AA-' to 'At' (Partington, 2017). The Indian state communicates its sovereignty anxiety as CPEC cuts through the Gilgit-Baltistan borderland area of Kashmir over which India claims sovereignty. In addition, China's debt-levered expropriations (e.g., Sri Lanka's Hambantota and Pakistan's Gwadar ports) intensify the geoeconomic-geopolitical struggles for other regional ports/transport corridors (e.g., Iran's Chabahar) by India and Japan. New Delhi, dissatisfied with the territorial challenges coming from the CPEC project, boycotted China's Belt and Road Forum that occurred on 14-15 May 2017. In cooperation with Japan, it advances its Chabahar project and constructs alternative imaginaries (e.g., Asia-Africa Growth Corridor which is a new sea route connecting Indian, African and Southeast Asian ports) (Beri, 2017). Likewise, Mohamad Mahathir, on returning to office as the Prime Minister of Malaysia in May 2018, cancelled two OBOR-related infrastructural projects three months later because of rising worries over their rising debt burden and his conviction that the deals are too favourable to China. And, in July 2018, the US joined the geostrategic search for alternative spatial fixes in the region by promoting an IndoPacific vision of Indian and Pacific Oceans.

\section{CONCLUSIONS}

This article deploys a critical discursive-cum-material approach to examine the dialectical intertwining of geoeconomics and geopolitics as multiple players, encouraged by the Chinese party leadership and state as they seek to reorder key socio-spatial features of the world market. Responding to the 2008 global financial crisis, the Chinese government promoted a stimulus package and policies to increase liquidity and demand. This reinforced overcapacities and intensified the triple bubbles. As the new Xi-Li leadership went into crisis-management mode, 'Likonomics' proved less resonant than Xi's 'new normal' discourse and OBOR. Discursively, OBOR builds 
on the earlier 'Go West' and 'Go Out' policies and uses a panoply of rhetorical and visualization techniques to consolidate support for this new imaginary. Thus, as a spatial fix, OBOR is mediated by hope and fear discourses that energize actions. Materially, this spatial fix launches another stimulus package that can displace China's triple bubbles abroad by creatively rearticulating sociospatial organizations, infrastructure development, financing mechanisms, and security protection. Yet it also intensifies unevenness, contradictions and conflicts of interest that arise from China's displacement of overcapacity and spreads debt burden abroad. New geoeconomic practices of bilateral loan-debt contractuality deepen debt traps, especially in some financially-fragile developing countries. This allows China to acquire geostrategic infrastructure at the expense of some developing countries that are locked into vicious debt cycles. These infrastructural expropriations not only intensify local resistance; they also accentuate geopolitical-geoeconomic counter-tendencies along pre-existing security fault-lines and struggles for resources. This is reflected in the emergence and consolidation of a governance configuration around security to complement the governance configurations around production and finance. I illustrated this by considering the China-Pakistan Economic Corridor as one instance of the dialectical intertwining of China's geoeconomic-connectivity hope to export overcapacity and the geopolitical-geoeconomic struggles for spatialization coming from the worries of China's debt-levered expropriations of regional geostrategic sites/resources/influence. In this way, I have suggested that an affective turn sensitive to hope and fear discourses can provide a more nuanced account of the energies that are involved in the promotions and struggles in the making of spatial fixes across different sites and scales.

\section{Endnotes}

1 The 'One Belt One Road' was renamed by China as the 'Belt and Road Initiative' (BRI) in the Belt and Road Forum held between 14 to 15 May 2017.

2 Sparke's 'double vision' can be elaborated by showing how the interaction of discursive, structural, technological and agential selectivities condenses geoeconomic and geopolitical imaginaries and practices into specific spatio-temporal 
fixes (for the theoretical arguments on cultural political economy and other cases, see Sum and Jessop, 2013).

${ }^{3}$ By mid-2009, there were at least 3,800 LGFVs at the provincial, prefectural, and even county/city district levels (Meng, 2009).

4 The author would like to thank an anonymous reviewer on the Chang-tu-ji projects and South Korea's New Northern Policy.

${ }^{5}$ Loan-debt contractuality takes many forms. In China, initial loans mainly come from policy banks, SOBs and special funds. Contracts can then be extended via consortium loans; joint private equity; and joint debt issuance.

\section{Acknowledgements}

The author wants to thank two anonymous reviewers, the co-editor, and Bob Jessop for their valuable feedback. She also wants to thank the Post-Growth College of the Institute of Sociology in Friedrich-Schiller University at Jena (Germany) for support while finalizing this article.

\section{Disclosure Statement}

No potential conflict of interest was reported by the author.

\section{ORCID}

Ngai-Ling Sum http://orcid.org/0000-0002-4285-1351

\section{References}

Agnew, J. (1994). The territorial trap: the geographical assumptions of international relations theory. Review of International Political Economy, 1(1), 53-80.

Agnew, J. \& Corbridge, S. (1995). Mastering space: Hegemony, territory and international political economy. London: Routledge. 
Ahmed, S. (2004). The cultural politics of emotion. Edinburgh: Edinburgh University Press.

Ashley, R. (1987). The geopolitics of geopolitical space: toward a critical social theory of international politics. Alternatives, 12, 403-434.

Babb, S. (2013). Washington Consensus as a transnational policy paradigm. Review of International Political Economy, 20(2), 268-97.

Balanchandra, P. (2017). Sri Lanka proposes to cut Chinese stake in Hambantota $\begin{array}{llllll}\text { port } & \text { from } & 80 & \text { to } & 60 & \text { per }\end{array}$ http://www.newindianexpress.com/world/2017/mar/18/sri-lanka-proposes-to-cutchinese-stake-in-hambantota-port-from-80-to-60-per-cent-1582866.html

Beri, R. (2017). India's new initiative in Africa: the Asia-Africa Corridor, IDSA Comment, 13 June, https://idsa.in/idsacomments/indias-new-initiative-in-africaasia-africa-growth-corridor_rberi_130617

Booth, K. \& Wheeler, N. (2007). The security dilemma. London: Palgrave.

Brown, R. (2015). Where would the Silk Road lead?, https://academiccommons.columbia.edu/.../Spring-2016-FINAL-FINAL-2-7193.pdf

Campbell, D. (1998). Writing security: United States foreign policy and the politics of identity, $2^{\text {nd }}$ ed. Minneapolis, MN: University of Minnesota Press.

Cai, P. (2017). Understanding China's One Belt One Road Initiative, 22 March, https://www.lowyinstitute.org/publications/understanding-belt-and-road-initiative Chinese Executive Leadership Academy, Jingganshan (2014). Xi's 'new normal' theory. http://www.celaj.gov.cn/english/www/19/2014-11/462.html

Chen, B. (2013). Third Plenum to accelerate market-oriented financial reform, 9 November, http://www.china.org.cn/china/2013-11/09/content 30550944.htm

Centre for Strategic and International Studies (2015). Building China's 'One Belt, One Road', 3 April, http://csis.org/publication/building-chinas-one-belt-one-road

Chakraborty, S. (2017). Is China colonializing Pakistan?, 15 May, http://www.dailyo.in/politics/pakistan-china-cpec-pok-dawn/story/1/17245.html

Chaudhury, D. (2017). China effect? Myanmar too facing a debt crisis, Economic Times 12 May, http://economictimes.indiatimes.com/news/international/worldnews/china-effect-myanmar-too-facing-a-debt-crisis/articleshow/58634899.cms

Chesnais, F. (2014). Fictitious capitals in the context of global over-accumulation and changing international economic power relationships. In R. Bellofiore \& G. Vertova, 
(Eds.), The great recession and the contradictions of contemporary capitalism (pp. 65-82). Cheltenham, UK: Edward Elgar.

China Daily (2015a). China's top auditor warns of local government debt risk, 28 June, http://www.chinadaily.com.cn/china/2015-06/28/content 21126725.htm

China Daily (2015b). China's 2015 diplomacy focuses on 'Belt and Road', 8 March, http://www.chinadaily.com.cn/china/2015twosession/2015-

03/08/content 19750295 2.htm

Clarke, M. (2015). Understanding China's Eurasia pivot. The Diplomat, 6 September, http://thediplomat.com/2015/09/understanding-chinas-eurasian-pivot/

Clover, C. \& Hornby, L. (2015). China's great game. Financial Times, 12 February, https://www.ft.com/content/6e098274-587a-11e5-a28b-50226830d644

Coonan, C. (2014). Ghost cities a symbol of slowdown in China's property market. Irish Times, 28 October, http://www.irishtimes.com/business/commercialproperty/ghost-cities-a-symbol-of-slowdown-in-china-s-property-market1.1978425

Dalby, S. (1991). Critical geopolitics: discourse, difference and dissent. Environment and Planning D: Society and Space, 9(3), 261-283.

Dobbs, R., Lund, S., Woetzel, J., \& Mutafchieva, M. (2015). Debt and (not much) deleveraging. McKinsey Global Institute, http://www.mckinsey.com/insights/economic studies/debt and not much delev eraging

Dawn (2017). Exclusive: CPEC master plan revealed. https://www.dawn.com/news/1333101

Elden, S. (2013). Geo-political economy. Society and Space 18 https://societyandspace.com/2013/11/18/geo-political-economy-virtual-themeissue/

Essex, J. (2013). Development, security, and aid. Athens, GA: University of Georgia Press.

Foucault, M. (1980). Power/knowledge. New York: Vintage.

Foucault, M. (2008). Security, territory, population. Lectures at the Collège de France, 1977-1978, trans. G. Burchell. Basingstoke: Palgrave.

Goh, B., Martina, M. \& Shepherd, C. (2017). Local, global security firms in race along China's 'Silk Road'. Reuters, 24 April, http://uk.reuters.com/article/us-chinasilkroad-security-analysis-idUKKBN17P10Y 
Graceffo, A. (2017). China's Push for the One Belt One Road (OBOR) Initiative. $\begin{array}{llll}\text { Foreign } & \text { Policy } & 15 & \text { Journal, }\end{array}$ https://www.foreignpolicyjournal.com/2017/05/15/chinas-push-for-the-one-beltone-road-obor-initiative/

Gregory, D. (2008). The rush to the intimate: counterinsurgency and the cultural turn in later modern war. Radical Philosophy, 150, 8-23.

Hall, D. (2015). Why public-private partnerships don't work. Public Service International Research Unit, University of Greenwich, UK.

Hartig, F. (2016). Chinese public diplomacy: The rise of the Confucius Institute. London: Routledge.

Harvey, D. (1982). Limits to capital. Oxford: Basil Blackwell.

Harvey, D. (2009). The new imperialism. Oxford: Oxford University Press.

Haushofer, K. (1941). Der Kontinentalblock: Mitteleuropa, Eurasien, Japan. Berlin: Eher.

Hsing, Y. (2010). The great urban transformation: Politics of land and property in China. Oxford: Oxford University Press.

Hsu, S. (2015). China's volatile stock market and its implications. China Policy Institute Policy Paper 2015: No 7, https://www.nottingham.ac.uk/cpi/documents/policypapers/cpi-policy-paper-2015-no-7-hsu.pdf

Hu, F. (2015). How China's 100 million 'stir fry' investors helped cause the market crash. Huffington Post, 13 July, http://www.huffingtonpost.com/fred-hu/chinainvestors-market-crash b 7786296.html

Hu, Y. (2015). NDRC to promote innovative public-private partnership model. 25 May, http://english.cntv.cn/2015/05/25/VIDE1432537204693287.shtml

Jessop, B. (2016). Territory, politics, governance and multispatial metagovernance. Territory, Politics, Governance, 4(1), 8-32.

Jessop, B. \& Sum, N-L. (2018). Geopolitics: Putting geopolitics in its place in cultural political economy. Environment \& Planning A, 50(2), 474-478.

Jin, J. (2015). The true intent behind China's AllB strategy. Fujitsu Research Institute, 25 August, http://www.fujitsu.com/jp/group/fri/en/column/message/2015/2015-08-25.html Kolo, V. (2014). China: hard landing in 2015? 24 December, Chinaworker Info, http://chinaworker.info/en/2014/12/24/8759/ 
Lam, W. (2009). Hu Jintao unveils major foreign-policy initiative. China Brief 24(9), 24.

Lam, W. (2014). Members of the Xi Jinping clique revealed. China Brief 14(3) http://www.jamestown.org/programs/chinabrief/single/?tx ttnews\%5Btt news $\% 5$ $\mathrm{D}=41933 \#$.VkRyrmzFbug

Lin, C-P. (2015). AlIB and One Belt One Road: Dominating Eurasia without war. 21 April, http://bit.ly/2yDgkzS (in Chinese)

Lin, G. (2014). China's landed urbanization: state power reshuffling, land commodification, and municipal finance in the growth of metropolises. Environment and Planning A, 46(8), 1814-1835.

Lopez, L. (2016). China just started unloading its biggest problem on the rest of the world, and the world is already freaking out. Business Insider, 6 April, http://www.businessinsider.de/china-unloads-overcapacity-on-the-world-2016$4 ? r=U K \& I R=T$

Lu, Y. \& Sun, T. (2013). Local government financing platforms in China: a fortune or misfortune. IMF Working Paper No. 13/243, https://www.imf.org/external/pubs/ft/wp/2013/wp13243.pdf

Luttwak, E. (1990). From geopolitics to geo-economics: logic of conflict, grammar of commerce. The National Interest, 20(1), 17-23.

Mackinder, H. (1904). The geographical pivot of history. Geographical Journal, 23(4) 421-437.

Madan, T. (2016). What India thinks about China's One Belt, One Road initiative" http://www.brookings.edu/blogs/order-from-chaos/posts/2016/03/14-india-chinaasia-connectivity-madan

Magnier, M. (2015). China economic growth falls below 7\% for first time since 2009. http://www.wsj.com/articles/china-economic-growth-falls-below-7-for-first-timesince-2009-1445221368

Marx, K. (1973). Grundrisse:_Foundations of the critique of political economy (rough draft). Harmondsworth, UK: Penguin.

Marx, K. (1998). Capital: volume 3. Marx-Engels Collected Works, vol. 37. London: Lawrence \& Wishart <1894>

Massumi, B. (2002). Parables for the virtual: Movement, affect, sensation. Durham, NC: Duke University Press. 
Meng, Y. (2009). Banks need to be cautious in lending to local government financing platforms. Jin Rong Shi Bao, 4 November, http://bank.jri.com.cn/2009/11/0405026389728.shtml

Moore, A. \& Perdu, N. (2014). Imagining a critical geopolitical cartography. Geography Compass, 8(12), 892-901.

Morozova, N. (2014). Can there be ethical politics? Rethinking the relationship between European Geopolitics and Russian Eurasianism. National Research University, Higher School of Economics, WP BRP 08/IR/2014, https://www.hse.ru/data/2014/11/19/1101015101/08IR2014.pdf

$\mathrm{Ng}$, A. (2015). Navigating the Belt and Road. Ernst and Young, http://www.ey.com/Publication/vwLUAssets/EY-navigating-the-belt-and-roaden/\$FILE/EY-navigating-the-belt-and-road-en.pdf

Ohmae, K. (1990). The borderless world. New York: Harper Business.

Olive, C. (2016). China's hard landing began last year, and it's going to get worse. South China Morning Post, 1 June, http://www.scmp.com/business/globaleconomy/article/1960479/chinas-hard-landing-began-last-year-and-its-going-getworse.

Ó Tuathail, G. (1996). Critical geopolitics: The politics of writing global space. Minneapolis, MN: Minnesota University Press.

Ó Tuathail, G. \& Agnew, J. (1992). Geopolitics and discourse: practical geopolitical reasoning in American foreign policy. Political Geography, 11(2),190-204.

Partington, R. (2017). China's credit rating cut to A+ by S\&P over rising debt fears. The Guardian, 21

September, https://www.theguardian.com/business/2017/sep/21/sp-cuts-chinas-credit-ratingto-a-over-rising-debt-fears

Perkmann, M. \& Sum, N-L. (Eds.) (2002). Globalization, regionalization and crossborder regions. Basingstoke: Palgrave.

Pickles, J (2004). A history of spaces: Cartographic reason, mapping, and the geocoded world. New York: Psychology Press.

PTI (2017). China willing to give Sri Lanka \$ 24 billion more as part of OBOR, The Economic Times, 17 May, http://economictimes.indiatimes.com/articleshow/58716674.cms?utm source=co ntentofinterest\&utm medium=text\&utm campaign=cppst

Qi, D. (2010). 'GDPism' and people's livelihood in China. EAI Bulletin 5 May 
Rasmus, J. (2015). Systemic fragility in the global economy. Atlanta, GA: Clarity Press. Ratzel, F. (1897). Politische Geographie. München: R. Oldenbourg.

Ratzel, F. (1940). Erdenmacht und Volkerschicksal. Stuttgart: Stuttgart University Press.

Rifaat, H. \& Maini, S. (2016). The Chinese-Pakistan Economic Corridor. https://www.stimson.org/sites/default/files/file-attachments/The\%20China-

Pakistan\%20Economic\%20Corridor\%20-\%20Final.pdf

Rudolf, M. (2015). China's 'Silk Road' initiative is at risk of failure. The Diplomat, 24 September, http://thediplomat.com/2015/09/chinas-silk-road-initiative-is-at-risk-offailure/

Sekine, E. (2014). A security market view of the Third Plenary Session of the $18^{\text {th }}$ Congress of the CPC Central Committee, Nomura Journal of Capital Markets 5(4), http://www.nicmr.com/nicmr/english/report/repo/2014/2014spr03.pdf

Sheehan, S. (2017). The problem with China's One Belt One Road strategy, The Diplomat, 24 May, http://thediplomat.com/2017/05/the-problem-with-chinas-onebelt-one-road-strategy/

Shirk, S. (2008). China: Fragile superpower. New York: Oxford University Press.

Sparke, M. (2007). Everywhere but always somewhere: critical geographies of the Global South. The Global South, 1(1), 117-126.

Sparke, M. (2014). On the double vision of geopolitics and geoeconomics: connecting contradictory geostrategic discourses to the contradictions of uneven global development. ISA Conference Paper, https://www.researchgate.net/publication/263607661_ON_THE_DOUBLE_VISIO N_OF_GEOPOLITICS_AND_GEOECONOMICS_CONNECTING_CONTRADIC TORY_GEOSTRATEGIC_DISCOURSES_TO_THE_CONTRADICTIONS_OF_U NEVEN_GLOBAL_DEVELOPMENT

Standard and Poor's (2015). China's Corporate debt looms large. http://www.financeasia.com/News/399907,china8217s-corporate-debt-loomslarge.aspx

Sum, N-L (2013). A cultural political economy of financial crisis: The turn to BRIC and the subalterns in China. Economy \& Society, 42(4), 543-570.

Sum, N-L. (2017).The making of the subaltern subjects: embodiment, contradictory consciousness and re-hegemonization of the Diaosi in China. Globalizations, 14(2), 298-312. 
Sum, N-L. \& Jessop, B. (2013). Towards a cultural political economy. Cheltenham, UK: Edward Elgar.

Summers, T. (2016). China's new silk road. Third World Quarterly, 37(9), 1628-1643.

Sun, Q. \& Fu, X. (2011). China's battle against the global economic crisis. In X. Fu (Ed.), China's Role in Global Economic Recovery (pp. 10-25). New York: Routledge.

Swaine, M. (2015). Chinese views and commentary on 'One Belt One Road' Initiative. China Leadership Monitor, Summer Issue 47, http://www.hoover.org/research/chinese-views-and-commentary-one-belt-oneroad

Tan, W. Z. (2015). China's One Belt, One Road project could aid recovery in global shipping. $24 \quad$ December, http://www.lloydsloadinglist.com/freightdirectory/news/China\%E2\%80\%99s-One-Belt-One-Road-project-could-aidrecovery-in-global-shipping/65190.htm\#.VzzLS-TILal

Tiezzi, S. (2014). The New Silk Road: China's Marshall Plan? The Diplomat, 6 November http://thediplomat.com/2014/11/the-new-silk-road-chinas-marshallplan/

Venkatachalam, K. (2017). Can Pakistan afford CPEC?, The Diplomat, 16 June http://thediplomat.com/2017/06/can-pakistan-afford-cpec/

Wang, J-S. (2013). North, south, east, and west - China is in the 'middle': A geostrategic chessboard (in Chinese). World Affairs, 01 November, 27-52.

Wang, Y. (2014). China's new foreign policy: Transformations and challenges reflected in changing discourse. The Asian Forum, http://www.theasanforum.org/chinas-new-foreign-policy-transformations-andchallenges-reflected-in-changing-discourse/

Wang, Y. (2015). China's 'New Silk Road': A case study in EU-China relations. In A. Amighini \& A. Berkofsky (Eds), Xi's policy gambles: The bumpy road ahead (pp. 93-110). Milan: Italian Institute for International Political Studies.

Wu, F. (2015). Commodification and housing market cycles in Chinese cities. International Journal of Housing, 15(1), 6-26.

Wu, F., Xu, J. \& Yeh, A. (2007). Urban development in post-reform China: State, market and space. London: Routledge. 
Xinhua Finance Agency (2015). China's PPP financing may dominate Belt and Road Infrastructure investment, http://en.xinfinance.com/html/OBAOR/Analysis/2015/101877.shtml

Zhang, S. \& Miller, M. (2017). Behind China's Silk Road vision: Cheap loans, heavy debt and growing risk. 15 May, Reuters, http://www.reuters.com/article/us-chinasilkroad-finance-idUSKCN18B0YS

Zhao, D. (2009). The mandate of heaven and performance legitimation in China. American Behavioral Scientist, 53(3), 416-433. 